\title{
Dean Mahomet's Travels: Multiple Borders, Cross-Cultural Spaces, and Syncretic Identity (Article)
}

\author{
CHANDRAVA CHAKRAVARTY \\ West Bengal State University
}

$\mathrm{M}$

y study of Dean Mahomet's Travels, written in 1793-94, highlights the syncretic nature of experiences unleashed by European colonialism. Travels offers a fascinating account of the life, experience, and perspective of an Indian Muslim under the East India Company. Mahomet (also known as Sake Dean Mahomed) traveled extensively through Northern India and wrote about his experiences for a fictitious European friend. This essay studies the text as an example of resistance and self-fashioning through the assimilation and subsequent subversion of Orientalist ethnography. Mahomet's work is a suitable rejoinder to the historically pertinent question framed by Dipesh Chakrabarty, "Who speaks of the Indian past?" We hear, perhaps for the first time, the voice of a "subaltern" writer, who manipulates the Eurocentric historiography of the colonial times to challenge the "center" and "margins" of the Western imperial discourse. ${ }^{1}$

I.

Mahomet's Travels offers a unique response to geographical space as he traversed various national, racial, linguistic, religious, and cultural borders and upheld a non-Western perception of the process of colonial interface. As a man who served the East India Company in various capacities, Mahomet recounted his experience with large portions of Northern India and also with Europeans as the East India Company conquered considerable parts of North India. After leaving the Indian shore with his master, Mahomet traveled through Europe between 1781 and 1854, emigrated to Ireland, and married a Protestant Anglo-Irish woman named Jane Daly. His Indian-Irish family again emigrated to London in 1807 in search of livelihood, where he experienced severe hardships as a new settler. Multiple border crossings, on the one hand, liberated Mahomet from the constraints of colonial subalternity; on the other hand, his status as a colonized subject in Ireland and England, struggling to gain a foothold, narrates a different reality of diasporic life.

Dean Mahomet's Travels, therefore, serves multiple purposes: it is a work written about colonial encounters in India from the perspective of a non-Westerner; India in Mahomet's letters is narrated by an "insider" who does not exoticize India but explains the country's multicultural and religious life with authenticity. Again, the idea of authenticity or veracity, so fraught and problematic in the context of travel writing, acquires a new twist with Mahomet's work. It is written by an expatriate Indian who had been trying to establish himself as a member of the British society. He is thus both an insider and an outsider with regard to both India and Britain. Even after acculturating himself in Western life, Mahomet never hesitated to "sell" his Indian identity for his various business enterprises in Ireland and

1. Dean Mahomet, The Travels of Dean Mahomet: An Eighteenth-Century Journey through India, edited with an introduction and biographical essay by Michael H. Fisher (Berkeley: University of California Press, 1997) < http://ark.cdlib.org/ark:/13030/ft4h4nb20n/> The text obtained from UC Press E-Book Collection has no pagination. Hence all quotations will be cited by sections/letter numbers. 
Britain. Therefore, for Mahomet, the criteria of "difference" and "otherness" acquired a complex function in the context of India and Europe: as an expatriate writer, he is an "outsider" to his colonized countrymen, while for his Western readers, he is an "insider" to the country he describes. However, to his target readers, he is strangely positioned both as an "insider" to their world and an immigrant "outsider." This dynamic works throughout his travels, resulting in a subject position that sways curiously between "we" and "they" and makes the travel account an apt paradigm of unsettled borders. Mahomet's emigration to Europe was, perhaps, illegal and explains why he never returned to India. And yet as a visitor, his status in Europe was much elevated compared to other Indians. Indeed, although "thousands of Indians made the trip to Europe over these years, apparently no one else had exactly Dean Mahomet's status. Most were sailors, servants, wives, or mistresses of Europeans. A few were travelers or visiting dignitaries. Dean Mahomet clearly fits into none of these categories." ${ }^{2}$ In fact, during those early phases of British-India cultural interface, Mahomet impresses as a truly transcultural individual, neither assimilated fully into the European culture nor completely relegated to the subaltern status of the colonized. Michael Fisher further explicates Mahomet's unique position in Cork society after he arrived in 1784: "Whatever relationships Dean Mahomet may have had with . . other Indians, his situation remained quite different from any of theirs. . . His literary achievement, Travels, received the endorsement of hundreds of Ireland's leading citizens, .... [and this proves] that they regarded him as a man of culture. Yet he remained someone quite apart from Irish society at the time."3

For Dean Mahomet, diaspora was both an emergent space and an interpretative frame that enabled him to debunk the claims made for racially purified and homogeneous identities. Mahomet had willingly left India and his "home" for the center of power. Hence desire for homeland does not surface in the pages of Travels. The image of a journey dwells in the heart of diaspora, but it is also a journey about settling down and putting roots elsewhere.

Mahomet's travels through Ireland and England were essentially about his struggle over the social process of "belonging" to another country. ${ }^{4}$ India, his country of origin, was no longer the "home" to which he wished to return; yet he cherished a deep understanding of life there and deploys this special knowledge to strengthen his social and cultural roots in Ireland.

Mahomet's diasporic condition appropriately echoes Avtar Brah's concept of diaspora as multi-locationality within and across cultural, territorial, and psychic boundaries. ${ }^{5}$ The identity of the writer in such a work, where boundaries of home, nation, and culture are fuzzy, cannot be characterized by the simplistic notion of diasporic "rootlessness." In fact, Brah succinctly observes that the multi-placedness of home in the diasporic imagination does not necessarily mean that diasporic subjectivity is rootless. While he was writing his Travels, Mahomet psychologically belonged to Ireland more than he belonged to India. As we look at such an example of an eighteenth-century voluntary emigration, Dean Mahomet's travel writing reveals new transnational spaces of experience that interact complexly with the experiential framework represented by the country of origin and the countries of settlement. ${ }^{6}$

2. Michael Fisher, Section "Dean Mahomet in Ireland and England (1784-1851)," in Travels of Dean Mahomet.

3. Michael H. Fisher, Counterflows to Colonialism: Indian Travelers and Settlers in Britain, 1600-1857 (New Delhi: Permanent Black, 2004), 88. 89.

4. See Avtar Brah, The Cartographies of Diaspora: Contesting Identities (London: Routledge, 1996), 179-

5. Brah, Cartographies of Diaspora, 194.

6. See David Morley, Media, Mobility, Identity (London: Routledge, 2000). 
II.

Mary Louise Pratt has influentially formulated the complex relationship between the metropolis and the periphery in travel writing. According to Pratt, "While the imperial metropolis tends to understand itself as determining the periphery (in the emanating glow of the civilizing mission or the cash flow of development, for example), it habitually blinds itself to the ways in which the periphery determines the metropolis-beginning, perhaps, with the latter's obsessive need to present and re-present its peripheries and its others continually to itself. Travel writing, among other institutions, is heavily organized in the service of that imperative." 7

The connection between the emergence of European imperialism and travel writing is undeniable and intimate as it became an important medium for the circulation of ideas around the world. It was a vital medium of cross-cultural contact and exchange - a form that profoundly influenced global perceptions about diverse places, cultures, manners, and people. Despite the fact that travel writing has a history of its own, Pratt pertinently argues that it is intrinsically linked to the process of colonization. As she talks about the emergence of Europe's "planetary consciousness," she describes it as "a basic element constructing modern Eurocentrism, that hegemonic reflex that troubles westerners even as it continues to be second nature to them." 8 Foucault also reminds us that the Enlightenment culture of reason sustained itself by exploring what lay beyond the periphery of its knowledge systemmadness, sexuality, and the Orient. With the establishment of European imperialism across the globe, representation of "otherness" became a predominant characteristic of travel literature. Travel was no longer about the journey of an individual and his or her growth in the course of that journey but was saturated with colonial motives and ideology. Consequently, search for the "other" from a subjective, personalized perspective was inflected with colonial points of view. To use the words of Michael Frank, this is the realm of "imaginative geography," by which he means "a strategy of identity construction which equates (spatial) distance with (cultural, ethnic, social) difference, associating the non-spatial characteristics of 'self' and 'other' with particular places." According to Edward Said, this is what Orientalist historiography achieved through the circulation of racial and cultural stereotypes. Nevertheless, one positive offshoot of the emergence of "planetary consciousness" was a growing interest in other peoples and cultures, a trend that made the publication of Mahomet's Travels, written consciously for the Western audience, possible. As Susan Bassnett writes, "The old boundaries have no validity in a changed social environment, and out of this sense of uncertainty comes an interest in books that provide accounts of other cultures, books that focus upon difference." ${ }^{10}$ Yet, for Bassnett and others, travel writing is never an innocent account of what one sees; it is a construction of other cultures and people.

The "Oriental" as subject of Orientalist writing is predicated upon the contract between the civilized Western traveler and the barbaric denizens of the colonized land. I turn to Said's exact framing of the concepts: "The Oriental is given as fixed, stable, in need of investigation. No dialectic is either desired or allowed. There is a source of information (the Oriental) and a source of knowledge (the Orientalist)." ${ }^{11}$ Europe's responses to India or a

7. Mary Louise Pratt, Imperial Eyes: Travel Writing and Transculturation (London: Routledge, 1992), 6.

8. Pratt, Imperial Eyes, 15.

9. Michael C.Frank, "Imaginative Geography as a Travelling Concept: Foucault, Said and the Spatial Turn," European Journal of English Studies 13, no. 1 (2009): 61-77, 71.

10. Susan Bassnett, "The Empire, Travel Writing and British Studies," in Travel Writing and the Empire, ed. Sachidananda Mohanty (New Delhi: Katha, 2003), 8.

11. Edward Said, Orientalism (New York: Pantheon, 1978), 308. 
homogenized Eastern world had been consecrated to the reproduction of the non-West as the stereotypical "other" to Europe. As John Keay writes in India Discovered, "Two hundred years ago India was the land of the fabulous and fantastic, the 'Exotic East.' Travellers returned with tales of marble palaces with gilded domes, of kings who weighed themselves in gold, and of dusky maidens dripping with pearls and rubies. . . . It was like some glorious and glittering circus - spectacular, exciting but a little unreal." 12

In my analysis of Mahomet's work I shall attempt to show how such a neat binary is presented with ambivalence. Travel implies a departure and a return to the point of departure. The course of the journey, which involves both spatial and temporal lapses, considerably transforms the traveler's point of view and his relationship to his own culture. ${ }^{13}$ Pratt's idea of the "contact zone" becomes highly relevant here as, with the crossing of multiple geographical and cultural borders, Mahomet acquired a "contact" perspective that enabled him to constitute his subjects "in terms of co-presence, interaction, [and] interlocking understandings and practices, often within radically asymmetrical relations of power." 14 His changed identity in Europe, his relationship to the European imperial culture vis-à-vis his original status as a colonized servant of the East India Company, is worth mapping and analyzing. I turn to the history of the publication of Travels to highlight how the colonial enterprise produced intercultural spaces with no rigid hierarchy of power and how India remained for the colonizers not just a terra incognita for extraction or exploitation but also a pleasant memory to which the colonial masters felt a deep attachment. Indeed, according to Fisher, a "number of Protestant Irishmen who had served in India and held estates in southern Ireland" were his patrons; many of them named their estates "after places in India," including William Popham (Patna). ${ }^{15}$

Saidian historiography, being prescriptive in nature, ignores the reality of what can be described as "counterflows" to colonialism. ${ }^{16}$ In the context of the British-India colonial interface, Fisher notes, "Indian men and women have been traveling to England and settling there since about 1600, roughly as long as Englishmen have been sailing to India. Most historians of England, India and colonialism, however, tend to neglect accounts of and by Indian travelers" (153). Although several Indian travelers to Europe were not settlers, their accounts of Europe reversed the Orientalist gaze and provided a counter-hegemonic construction of the Occident. While a large number of travel writings by Indians were written in the nineteenth century, two eighteenth-century travelogues by Indians deserve special mention. These were written by officials of the Mughal court traveling to Europe on business: Mirza Sheikh I'tesamuddin's (1730-1800) The Wonders of Vilayet: Being the Memoir, Originally in Persian of a Visit to France and Britainin in 1765 and Mirza Abu Taleb Khan's (1752-1896) Travels of Mirza Abu Taleb Khan in Asia, Africa and Europe, written in the Persian language in two volumes. ${ }^{17}$ Both the volumes were translated into English by Charles

12. John Keay, India Discovered: The Recovery of a Lost Civilization (New York: Harper Collins, 2001), 13.

13. Stephen Bann, "Travelling to Collect: The Booty of John Bargrave and Charles Waterton," in Travellers' Tales: Narratives of Home and Displacement, ed. George Robertson et al. (London: Routledge, 1994), 155-64; also see Tabish Khair et al., eds., Other Routes: 1500 Years of African and Asian Travel Writing (Bloomington: Indiana University Press, 2005), 4.

14. Pratt, Imperial Eyes, 7.

15. Fisher, Section to Travels "Dean Mahomet in Ireland and England (1784-1851)".

16. I have used the term from Fisher's book Counterflows to Colonialism.

17. Mirza Sheikh I'tesamuddin's The Wonders of Vilayet was never published in the original. A flawed English translation appeared in 1827. I have consulted a translation of Kaiser Haq's The Wonders of Vilayet (UK: Peepal Tree Press, 2002); Mirza Abu Taleb Khan, Travels of Mirza Abu Taleb Khan in Asia, Africa and Europe During the Years 1799, 1800, 1801, 1802, and 1803. Written by Himself in the Persian Language. Trans by Charles Stewart (London: R. Watts, Broxbourne, Herts, 1814).

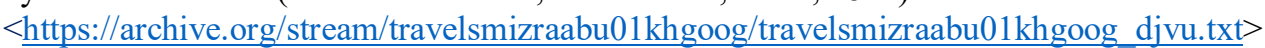


Stewart (1814). Mahomet's Travels is markedly different because it was the first travelogue written in English by an Indian. Moreover, the writer was an expatriate in Ireland and Britain, had intimate knowledge of Western culture, and, as an Indian settler in England, considered it his duty to cater to the Western world's curiosity about India and dispel certain false notions about his own country.

Soon after his arrival in Cork, Mahomet began learning the English language and literature to acculturate himself with the elite polite society of Ireland. As Fisher's biographical sketch tells us, "He mastered the classically polished literary forms of the day, complete with poetic interjections, erudite allusions, and classical quotations in Latin" ${ }^{18}$ His use of the epistolary form, a popular literary mode in eighteenth-century England, bespeaks Mahomet's commitment to attracting a Western audience. The language, literary form, and appeal to the elite society of Ireland as an Indian writer in the West granted him authenticity and power to narrate India for his European readers. Unlike Abu Taleb Khan, who lacked prior knowledge of British culture, Dean Mahomet's intimate knowledge about English life and manners empowered him to address facts of Indian life that were largely misunderstood or misrepresented by foreigners. Travels is, therefore, not simply an example of colonial mimicry but also an example of resistance to the politics of colonial representation. The location of his intervention is particularly relevant since the British East India Company was dominant in India from 1757-that is, even before the official beginning of colonial rule in 1858. As Krishna Sen observes, the Company's Governors-General "directly or indirectly controlled large swathes of upper India through a colonial-type administration, until the formal inception of the 'British Raj' in 1858. This is no mere historical quibble. The greater attraction of England over other European destinations for Indians was directly linked to the British East India Company's ascendancy over the French, Dutch, Portuguese and Danish East India Companies." 19

So Mahomet, who left his own community to be in the company of Mr. Baker of the East India Company, left no stone unturned to accommodate himself in British-Irish society. His marriage to Jane Daly, an Irish-Protestant woman, was a significant step toward assimilating with the Irish-Protestant elite. Indeed, according to Fisher, the "newly married couple seem[ed] to have been accepted by Cork society, suggesting that Dean Mahomet's marriage to Jane may have enhanced his social status". ${ }^{20}$ Mahomet must have seen his diasporic status as a position of greater power over his colonized fellow countrymen. However, in recounting Indian life, customs, people, and manners, he exercised the autonomy of his unique gaze to counter Orientalist knowledge of India.

III.

The empire and imperial conquests, as physical and ideological contact zones, engendered a complex identity in Mahomet as he saw himself positioned midway between his Indian countrymen and his European patrons. In the pages of his celebrated travelogue, Mahomet would occasionally identify with the members of the East India Company as he displayed unstinted allegiance to his patron, Mr. Baker, and other officers of the Company. Mahomet and several members of his class entered into a new relationship with the British administration as sipahi, or sepoy, in the Company's army. These were Indian infantry men dressed as semi-Europeans and trained in European military disciplines. He describes how

18. Fisher, note to Travels, Section "Dean Mahomet in Ireland and England (1784-1851)".

19. Krishna Sen, "Provincializing England: Victorian Domesticity and the Colonial Gaze," Postcolonial Interventions 2, no. 2 (2017): 5-6.

20. Fisher, note to Travels, Section "Dean Mahomet in Ireland and England (1784-1851)". 
the sepoys "serve as a strong reinforcement to a much less number of Europeans, and, on many occasions display great firmness and resolution" (Letter XVI). As Mahomet traversed large tracts of Northern India, his pride as a sepoy of the company is unmistakable. He frequently mentions "our camp" (Letter V) and describes how "we were advancing on our march" (Letter VIII). This, for Mahomet, was certainly a position of prominence and power. In Letter IX he describes the dignity and power of the Company's army as it marches on with him as a sepoy, subjugating huge terrains of North India. Having reached Dumdum, he describes how "we were all on the plain in military array" while the "natives . . f flocked from all quarters,. . . astonished at the sight." He then describes the sight in Eurocentric verse:

$$
\begin{aligned}
& \text { Of martial men in glitt'ring arms display'd, } \\
& \text { And all the shining pomp of war array'd; } \\
& \text { Determin'd soldiers, and a gallant host, } \\
& \text { As e'er Britannia in her pride cou'd boast. }
\end{aligned}
$$

Mahomet identifies himself with this "gallant host" rather than with the local people. It is worth noting that as a young boy Mahomet left his mother to be in the company of Mr. Baker, an officer of the East India Company, and refused to go back to her. In Letter III he justifies his decision by paying an effusive tribute to the generosity of his patron: "In gratitude ... I am obliged to acknowledge that I never found myself so happy as with Mr. Baker: insensible of the authority of a superior, I experience the indulgence of a friend; and the want of a tender parent was entirely forgotten in the humanity and affection of a benevolent stranger". While describing an Indian famine in the same letter, the idea of the "self" dramatically slips toward an undefined "other" as India becomes "their country" rather than his. "Little did the treasures of their country avail them on this occasion," he says. "A small portion of rice, timely administered to their wants, would have been of more real importance than their mines of gold and diamonds". Again the parallel between "their" (Indian) palanquin and "our" (Irish) sedan chairs also depicts a fluid, slippery "self."In Letter XXVIII the desperation to identify with the white dominant culture assumes a curious ambivalence. Mahomet talks about the white men's attitude toward snake charming: "Their incantation of snakes, in particular, has been attributed by many of your countrymen, to magic and the power of the devil". The pronouns their and your acquire an interesting play in Mahomet's narration. He seems to distance himself from the Indians (they) as well as the European readers (you), and then the narration veers toward an interesting confusion. Mahomet now describes a special species of hooded serpent with a big head and a "beautiful face resembling the human" and states, "It has been remarked by several, that this kind is supposed to be the same as that which tempted our first mamma, Eve." The people described collectively as "several" are likely to be the Europeans in India, who had witnessed this magical scene, and Mahomet is now certainly one of them, partaking of the culture that produced the story of Genesis.

Another passage in the Travels is worth our attention for its slipperiness between Mahomet's allegiance to the East India Company and his sympathy for the plight of an Indian ruler deprived of his ancestral land by Governor Hastings. After several failed attempts to subjugate Raja Cheytsingh of Ramnagar, the Company's forces, under the leadership of Captain Baker, Major Popham, and Captain Blair, approached the fortress of Cheytsingh. For Mahomet, he sees himself as part of the "we" who "now began the siege with the most lively ardor, and continued it for three days without intermission" until they "threw the enemy into the utmost confusion" before "three companies of determined Seapoy grenadiers, stormed the fort and rushed on the disordered enemy with manly resolution" (Letter XXXII). 
Mahomet's pride in being a part of this great victory is clearly manifest in the descriptions that follow highlighting the prowess and superior military tactics of the Company's army. He then sings a paean to the glory and courage of Captain Baker: "Whilst memory dwells on virtues only thine, / Fame o'er thy relics breathes a strain divine". With the nonchalance of an objective observer, Mahomet provides a detailed account of the suffering and humiliation borne by the Raja, who wrote several letters to the British Governor Hastings, begging mercy. He imputed his predicament to the whims of Providence: "Such was the happy situation of the Prince, and the philanthropy of the man, who shortly after became the sport of fortune, amidst the vicissitudes of life, and the trials of adversity" (Letter XXXIII). He also narrates how great discontent began to brew among the subjects of Raja Cheytsingh after his humiliation at the hands of the British: "The people dissatisfied with the fate of their late Raja, could, by no means, be reconciled to the sovereignty of the English" (Letter XXXIV). They are described as the "unruly natives" who put up a strong defense but were eventually dissipated and killed by the British musketeers. Mahomet's tone assumes the indifference of a philosopher reflecting on the futility of human resistance as he ponders over the merciless massacre of his fellow countrymen:

Alas! destructive war, with ruthless hand, Unbinds each fond connection, tender tie, And tears from friendship's bosom all that's dear, Spreading dire carnage thro' the peopled globe; Whilst fearless innocence, and trembling guilt, In one wide waste, are suddenly involv'd. (Letter XXXIV)

There is no indictment of foreign aggression, greed, and exploitation. The "innocent" and the "guilty" are not identified. The poetry acquires tragic intensity as Mahomet ponders the waste of war. The objective tone of philosophical speculation on warfare perfectly camouflages every feeling of guilt (if any) on the part of the narrator, who is also a perpetrator of the suffering of his own people. Perhaps Mahomet felt that he was different from his countrymen because he was constantly engaged in several strategic operations of the East India Company against the Indian rulers. Yet in Mahomet's travel writing, the shifting location of the "self" does not follow a linear trajectory. Mahomet inhabited a complex dialogic world of "self" and "other," marking a distinct move away from the binarism of colonial knowledge structure and entering a fluidity of identity.

IV.

If repeated confusion of identity emerges as a defining trait of Mahomet's travelogue, resistance to European ethnography is no less dominant. Of particular interest here is how Said sees resistance as a task of reclaiming, renaming, and reinhabiting the land in order to create an "alternative way of conceiving human history." ${ }^{21}$ Mahomet works within the structure of Orientalist knowledge, but while deriving information from English travel writers, he recontextualizes it and places it within an Indian perspective.

The most interesting feature of Mahomet's Travels is the manner in which the writer begins his travelogue. Although each of the thirty-eight letters is addressed to an anonymous "Dear Sir," suggesting intimacy, it seems that Mahomet did not write for any specific reader. The tone of cordiality and the mode of a personal epistle, addressed to a European friend 
eager for authentic information about India, was an effective strategy for making the narrator acceptable to a foreign readership. It created an intimate space for readers and writer to engage and allowed the author to move between private and public boundaries. The detailed descriptions of cities, landscapes, flora, fauna, customs, rituals, manners, and morals testify to the popularity of India as a place of tourism, business, and settlement for several Europeans to whom Mahomet seems to provide some sort of a travel guide. "Dear Reader," he begins,

since my arrival in this country, I find you have been very anxious to be made acquainted with the early part of my Life, and the History of my Travels: I shall be happy to gratify you; and must ingenuously confess, when I first came to Ireland, I found the face of everything about me so contrasted to those striking scenes in India, which we are wont to survey with a kind of sublime delight, that I felt some timid inclination, even in the consciousness of incapacity, to describe the manners of my countrymen, who, I am proud to think, have still more of the innocence of our ancestors, than some of the boasting philosophers of Europe. (Letter I)

Despite Mahomet's loyalty to his European patrons, the first letter makes some significant assertions. Apart from the eagerness of Colonel William Baillie of the East India Company, Mahomet was also compelled by the strangeness of Ireland to write about the "striking scenes" of India that produced not wonder but "sublime delight" in revisiting the world left behind. The Orientalist gaze is reversed as Ireland is presented as a land of "difference" or "otherness" to the writer, who took immense pride in recounting the "innocence" of his ancestors in India. As opposed to the established colonial binaries of East/West, primitive/civilized, unscrupulous/honest, Mahomet begins his travelogue with a new binary: innocence of India/artfulness of the West. The contrast between nature and art is further explored as Mahomet firmly positions his gaze between the simple values of Indian life and the contrived rationality of the Western world. In recounting the ignorance of a European official who, having relegated the simple faith of the Indians to superstition, urinated on the sacred shrine of a saint in Pirpahar, Mahomet expresses his contempt for the boastful Englishman, duly punished by Providence for undermining people's faith. Soon after the sacrilege, the Englishman is thrown from his horse and dies. Mahomet notes that his death presents "an awful lesson to those who, through a narrowness of judgment and confined speculation, are too apt to profane the piety of their fellow-creatures, merely for a difference in their modes of worship" (Letter VIII).

Interestingly, Mahomet does not describe India as much as he evokes India with sweeping generalizations about its fecundity and beauty, feeding the hunger of his European readers for the magical, exotic India of their imagination. However, the strategy does not appear to "otherize" India; rather, Mahomet asserts an intimate relationship with the country. What the evocation of India sustains is the contrast between nature and culture, spontaneity and contrivance: "The people of India, in general, are peculiarly favoured by Providence in the possession of all that can cheer the mind and allure the eye, and tho' the situation of Eden is only traced in the Poet's creative fancy, the traveller beholds with admiration the face of this delightful country, on which he discovers tracts that resemble those so finely drawn by the animated pencil of Milton" (Letter I).

The description of the Garden of Eden in Paradise Lost clearly echoes in the detailing of these scenes where Mahomet strikes a fine balance between the particular and the general. While Milton resolved the problem of describing a prelapsarian landscape with the help of postlapsarian language, Mahomet uses a similar artistic technique to create a bridge between the real and the exoticized. By reinscribing India as modern Eden, Mahomet very tactfully 
countered the colonizing gaze, which homogeneously presented the non-European colonies as barbaric and wild.

The tradition of Western ethnographic writing is also challenged in the descriptions of the people of India. India is described as a land of conviviality, benevolence, modesty, and chastity. From a kind of phantasmagoria inexplicable to the Western onlooker, Mahomet translates India, renders it comprehensible, because he partakes of both Indian and European cultures. He focuses, in terms that would have appealed to an eighteenth-century British audience, on the sociability and virtue of his countrymen and women:

Possessed of all that is enviable in life, we are still more happy in the exercise of benevolence and good-will to each other, devoid of every species of fraud or low cunning. In our convivial enjoyments, we are never without our neighbours; as it is usual for an individual, when he gives an entertainment, to invite all those of his own profession to partake of it. That profligacy of manners too conspicuous in other parts of the world, meets here with public indignation, and our women, though not so accomplished as those of Europe, are still very engaging for many virtues that exalt the sex. (Letter I)

Mahomet's descriptions of Muslim and Hindu customs and religion are offered with an unprejudiced openness. While Letters XII and XIII detail the ceremonies of circumcision and Muslim marriage, a highly idealistic portrait of the "Mahometan" is drawn to counter the Western perception of the people of Islamic countries as libidinous, violent, immoral, and debauched: "The Mahometans are, in general, a very healthful people: refraining from the use of strong liquors, and accustomed to a temperate diet, they have but few diseases, for which their own experience commonly finds some simple yet effectual remedy. ... The Mahometans meet death with uncommon resignation and fortitude, considering it only as the means of enlarging them from a state of mortal captivity, and opening to them a free and glorious passage to the mansions of bliss" (Letter XIV).

Letters XVII and XVIII recount Hindu customs and antiquity with deep reverence. The city of Benaras is described as the "Paradise of India" notable for its "salubrious air, fascinating landscapes, and the innocence of its inhabitants" (Letter XVII). But Mahomet's idea of Indian innocence does not estrange it from knowledge or wisdom. He copiously acknowledges the importance of the Brahmins as repositories of ancient knowledge and as unwearied practitioners of the discipline of astronomy. It is their heritage that has turned Benaras into a seat of learning, culture, piety, and pilgrimage. The most effusive appreciation of the Hindus is framed by a Muslim writer in these words:

While wasteful war spread her horrors over other parts of India, this blissful country often escaped her ravages, perhaps secured by its distance from the ocean, or more probably by the sacred character ascribed to the scene, which had, through many ages, been considered as the repository of the religion and learning of the Brahmins, and the prevailing idea of the simplicity of the native Hindoos, a people unaccustomed to the sanguinary measures of, what they term, civilized nations. (ibid.)

The dig in the last two lines at the Orientalist construction of the civilized/uncivilized binary is obvious. As against the rapacious greed and war-mongering of the colonizing nations, Mahomet upholds the simple life and philosophy of a religious sect who had valued learning and the wisdom of the Vedic scriptures more than material prosperity. The word they, which refers to the native Hindus, is rather ambiguously used. While it apparently points to the naturalization of the idea that colonizing nations are civilized and superior, it also opens to 
question whether the North Indian Brahmins, known for their orthodoxy, had actually accepted the cultural superiority of the European people. In fact, deep distrust toward "firingee" (European/infidel) ways persisted among different classes of Hindus, who were scared of defiling their religion by coming into contact with the foreigners.

The contrast between Western and Indian people continues as Mahomet memorizes the performances of the Indian dancing girls in the courts of the Nawabs (Letter XV). Both Indians and Europeans were drawn to their charms: "At a very youthful time of life, they are regularly trained in all the arts of pleasing, by a hackneyed matron, worn in the campaigns of Venus. ... [She] also procures them every article of dress that can set them off to advantage." Mahomet offers ample information about the nautch girls of India - the dresses, ornaments, cosmetics, makeup, and gestures that made them irresistible to their clients, although their lascivious gestures and movements never expose "any nudity" or "offend delicacy" (ibid.). The detailed description of the life and arts of these nautch girls leads to a comparison with European prostitutes. The nautch girls "have nothing of that gross impudence which characterises the European prostitutes," he says, for "their style of seduction is all softness and gentleness" (ibid.).

The elevated construction of the Indian prostitute matches Mahomet's glorification of Indian womanhood in Letter I. He endorses the nobility of Indian culture by positing women as the repository of Indian culture and social values. His characterization starkly contrasts with seventeenth-century European accounts of India, in which the women appeared to be both enticing and menacing. Racial and cultural distance made them enigmatic to the European gaze. Yet this was complicated by the practice of sati, which disturbs the "fantasy land" aspect of India. According to Kate Teltscher, "The presence of the sati-the widow who burns herself on her husband's funeral pyre" - was "a troubling and ambiguous figure who becomes a central topos in the European literature of India." 22 The practice of sati was fixated upon by the colonial authorities, and thus Indian women's bodies became complexly identified with Indian identity.

I shall borrow Pratt's idea of "autoethnography" to describe the significance of Mahomet's Travels. Pratt distinguishes between ethnographic and autoethnographic texts because ethnographic texts are the "means by which Europeans represent to themselves their (usually subjugated) others," while autoethnographic texts are "those the others construct in response to or in dialogue with those metropolitan representations" (7). Mahomet's travelogue fits largely into the mold of an autoethnographic work: although addressed to an English friend, it must have been read by the literate Indians living in Ireland and England and therefore must have had a heterogeneous reception. It helped Mahomet to enter the metropolitan literary culture of Ireland. It is thus important in "unraveling the histories of imperial subjugation and resistance" (9). It is interesting to note that to vindicate the greatness of Indian civilization, Mahomet internalized the European categories of progress, civilization, science, and knowledge, which enabled him to develop a sense of his Indian identity and debunk the Western prejudices against India. Mahomet focuses on the virtues, philosophy, genius, science, and antiquity of Indian learning, noting that

however strange their doctrine may appear to Europeans, yet ... [the] native Indians, or Hindoos, are men of strong natural genius, and are, by no means, unacquainted with literature and science, as the translation of the Ayeen Akberry [Ain-i-Akbari] into English, has fully evinced. We may trace the origin of most of the sciences, in their ancient manuscripts. Even before the age of Pythagoras, the Greeks travelled to

22. Kate Teltscher, India Inscribed: European and British Writing on India, 1600-1800 (New Delhi: Oxford University Press, 1995), 8. 
India for instruction: the trade carried on by them with the oldest commercial nations, in exchange for their cloth, is a proof of their great progress in the arts of industry.

(Letter XVIII)

Mahomet's appreciation of the Hindu way of life, the caste system, and rituals brings out a combination of European and Indian knowledge systems as he reinforces his argument by locating the philosophical bases of Indian beliefs and practices. The descriptions and selfexpressions acquire a transcultural character, derived from a "dialogic engagement with western modes of representation." 23

Mahomet's descriptions of India and its people, thus, stand in sharp contrast to the popular European representations of Indians. James Mill, an officer of the East India Company, offered an elaborate argument about the superiority of Europeans over Indians and justified the right of Europeans to rule the world in The History of British India (1817). Mill, who had never visited India, was proud to have based his arguments on objective facts that had a theoretical context. In the latter half of the eighteenth century, Adam Smith and Adam Ferguson had discussed various levels of civilization that placed Europeans at the highest level. To explain the superiority of Europe, their progress of civilization was linked to colonialism, worldwide travels, and scientific advancement. The torrid climate of the tropical regions was also held responsible for the supposedly unscrupulous and lazy nature of the Indians. F.M. Coleman, in his booklet Typical Pictures of Indian Natives, writes that the "Bengali, or as he is more often termed, the Bengali Baboo, belongs to a class who are as little distinguished for courage as any race in the world." 24 The Bania, Coleman added, draped a small cloth around his loin in privacy and ate rice in a small room (17-18). The tone of disdain and dismissal abounds in several comments by Europeans. We cannot but recall Macaulay's famous assertion of the superiority of the West in the Minute on Education. ${ }^{25}$ The obvious corollary to Macaulay's assertion of the poor state of learning in India and Arabia, as compared to the vast store of knowledge mastered by the Western nations, is that the Indians were fit for specific roles - either to be the native servants of the Europeans ${ }^{26}$ or to act as intermediaries between the British administrators and the colonized indigenous mass, a category described as "mimic men" by Homi Bhabha. ${ }^{27}$ Mahomet's sympathetic understanding of Indian life and reverence for Indian culture certainly counters the attitude of dismissal and condescension expressed by several European narratives about India.

23. Pratt, Imperial Eyes, 100.

24. F. M. Coleman, Typical pictures of Indian natives : being reproductions from specially prepared handcoloured photographs with descriptive letterpress, Seventh Ed (Bombay \& London: The "Times of India" Office, 1902), 32. <https://archive.org/details/in.ernet.dli.2015.72756/page/n53/mode/2up>

25. T. B. Macaulay, Minute on Education (1835): "We are not without experience to guide us. History furnishes several analogous cases, and they all teach the same lesson. There are in modern times . . two memorable instances of a great impulse given to the mind of a whole society, of prejudices overthrown, of knowledge diffused, of taste purified, of arts and sciences planted in countries which had recently been ignorant and barbarous," <http://www.mssu.edu/projectsouthasia/history/primarydocs/education/Macaulay001.htm>

26. See pictures of Indian servants of European gentlemen in The Costume and Customs of Modern India: From a Collection of Drawings by Charles D'Oyly, Esq., engraved by J.H. Clark and C. Dubourg with a preface and copious descriptions, by Captain Thomas Williamson (London: Edward Orme, 1813) Coleman also stated that the Indian natives made excellent servants.

27. Homi Bhabha, The Location of Culture (London: Routledge, 1994; repr. 2005), 121-31. 
$\mathrm{V}$.

Mahomet's Travels performs a complex function because of the historical conditions of its production. Mahomet had seen an India where the East India Company gradually expanded its dominion over the native states and attracted people who saw a lucrative future in serving the Company. The colonial binaries had not yet become ossified, and there were spaces for reciprocal relation between the Company and the Indian people. Highly enamoured of European culture, Mahomet had never hesitated to express his unswerving allegiance to his English masters as a sepoy in the Company's army. Later, as an expatriate entrepreneur in Ireland and England, Mahomet performed a conscious mimicry of the West by striving to become a member of the European society. In fact, the frontispiece of Travels displays an Indian of color in the attire of an Englishman. The portrait acquires its value as an instance of colonial mimicry. Mahomet's compromised position in England, the hybrid status of his Anglo-Irish-Indian family - and his reliance on "Indianness" for selling himself to his Western clientele - all bespeak a "betweenness" of status that posits Mahomet as an exemplar of "partial presence," that is, a metonymic representation of the colonial authority that he imitates and also undermines through "the repetitious slippage of difference and desire." ${ }^{28}$ Mahomet's self-representation acts as a paradigmatic case for arguing that the "contact zone" perspective goes beyond the Self/Other oppositions charted by Said in Orientalism and moves toward a more complex sense of the anxieties bred by the colonial rule - of belonging and un-belonging, of conformity and resistance. Mahomet's travelogue flouts the borders and boundaries of nation, geography, culture, and identity, and unsettles the very logic of the binary thinking that sustained European imperialism.

28. Bhabha, Location of Culture, 129. 